\title{
Image of the Destination for Mice Tourism
}

\author{
Assoc. Prof. Dr. Mariana Ianeva ${ }^{1}$, Ph. D. student Ralitsa Georgieva ${ }^{2}$ \\ Department "Economics of Tourism", University of World and National Economy, Sofia, Bulgaria
}

\begin{abstract}
:
The researched issue concerns building of an attractive image of the MICE tourism destinations. The attractiveness can be assessed by different factors, such as location, cultural and historical heritage, climatic conditions, health and safety policies, suitable transportation and other characteristics. Along with the above, the opportunities for experiences and emotions in the destination, that motivate the potential participants to travel, are essential for creating an image as an attractive destination for MICE tourism. The present study examines criteria for forming the attractiveness of destinations for events from the MICE complex. Presented are good practices of leading business tourism destinations, from which can be derived the necessary elements to create a competitive advantage, attract bigger tourist segments, and in particular - more business travelers.
\end{abstract}

Keywords: destination, image, MICE, attractiveness, location

\section{Introduction}

\section{Importance of the destination image for its development}

Meetings and congresses are said to be one of the fastest growing segments in tourism (Weber \& Ladkin, 2003; Oppermann, 1996). Various studies support this trend and point out business tourism as one of the main drivers for the development of the tourism destination and an important generator of income, employment and (foreign) investments. In addition to the economic benefits, this type of tourism provides opportunities for knowledge sharing, building social and other types of networks, which makes it important for the intellectual development and regional cooperation (Ianeva, 2020).

The elements connected to building a competitive advantage of the destination, as market demand conditions, as part of the strategies and structures of companies connecting and supporting industries of the business sector and others, provide opportunities for tourism, economic and social development. They also contribute to the local and regional economy by creating jobs and new investment projects. Investments aimed at innovative activities, both for the construction and maintenance of accommodation and infrastructure, and for the creation of sites with innovative products also provide a competitive advantage to the destination (Kaleychev, 2013). Modeling of this type of products, in the terms of the current market situation, the digitalized tourism market, the search for experiences in the destination and as a last 
trend - the investments in safe and healthy environment in the location and in specific business hotels can also be stand out as a tool for updating the MICE tourism product.

A destination may gain or lose attractiveness as a result of a change in the preferences of business tourists related to the motives for participation in the business event, also as a result of marketing campaigns conducted by tour operators for other resorts, due to depletion of its resources or as a result of negative events on the international tourism market (such as the global health crisis started at the end of 2019). Over time, a destination goes through several stages. The loss of its attractiveness for a certain type of tourism is a prerequisite for the introduction of new opportunities in offering other types of tourism products, repositioning and rebranding.

Morgan and Condliffe (2006) analyze that the study of a specific business event can provide only a limited overview of the economic benefits of the destination and it should be considered in the context of non-economic factors - social, environmental, cultural and its appearance. Clark (2006) concludes that destinations develop the MICE tourism industry similarly to the hotel industry - by providing a list of additional services such as spas, customer loyalty programs and in-room amenities. With regard to the business travel industry, this focus is on additional services, such as sightseeing tours, entertainment events and other features that attract large-scale events.

Sanders (2004) explores and presents several theories for organizing business events, emphasizing that although the appearance of the destination is evolving towards building more event centers in the destination, in order to attract more conferences and exhibitions, in reality there is no increase and the presence of more centers does not create more events and revenues from them. However, destinations continue to encourage the growth of conferences as a reliable opportunity for economic development. The paper summarizes that more significant for boosting the economic indicators is the marketing planning and management, integrated into the overall tourism strategy of the destination.

Priporas (2005) proposes several initiatives to build marketing strategies for the city of Thessaloniki, as a destination for MICE tourism, also applicable to other destinations aimed at the development of business tourism products. These involve the creation of a plan for the development of destination's image, including rich cultural history, specific promotional program, service quality training in the tourism sector and modernization of infrastructure and transport network.

In order to be created an attractive image, destinations for business events can form a repositioning strategy for attracting larger tourist segments, and in particular - a larger number of business travelers. For destinations, this can mean efforts aimed at changing the image formation of potential delegates and participants in the process of choosing a place for the business event. A successful approach can be found through the use of various factors influencing consumers' behavior, such as marketing, advertising and promotional programs. The effectiveness of marketing and promotional programs should not be focused only on specific tourism segments, but as part of the strategy, it is necessary to include specific marketing actions (McCartney, 2006). Destination Marketing Organizations (providing tourism management of the 
destination), hotel, exhibition centers and tour operators offering attractive package offers for the respective destination can all participate in building the attractiveness (image) of the destination.

As a result of the development and establishment of the value of the economic benefits that MICE tourism provides for the destination, the organization of business events worldwide develops, which leads to the importance of this type of tourism for the global tourism market as part of the marketing plan for destination management.

It can be concluded that MICE tourism is inextricably linked with the development of business in general - increasing the volume of international business leads to a greater number of trips related to its management. MICE also create the link between culture and business. International programs in the scope of business events influence the development of other types of tourism - cultural, historical, spa tourism, which greatly increases the attractiveness of tourist destinations.

After clarifying the importance of business tourism for the development of the destination, it is necessary to explore specific criteria that would help to ensure the competitive advantages of destinations for MICE.

\section{Criteria for building the image of the destination for MICE tourism}

There are studies based on various criteria for classifying attractive destinations for events from the MICE complex. In order to maintain a competitive position on the market and offer innovative products in business tourism, it is necessary for tour operators to study similar studies for topical business destinations.

Tourism destinations are a major component for the development of tourism products, from the position of availability of specific natural and anthropogenic resources, infrastructure and superstructure (Tsonev, Kaleychev, 2018). They can be distinguished as leading or dominant in the number of conferences and congresses held, from the perspective of the costumers' preferences, in terms of opportunities for entertainment and additional activities in the visited location and others. Destinations are also arranged on regional principle and number of organized events basis. A similar systematization is made by leading cities and the volume of tours in them. International business tourism associations also identify other factors on the basis of which business destinations can be arranged, such as improving the technological factor, reducing the cost of organizing visual conferences and others.

The distinction between different types of MICE events - corporate, of associations, government and others, is an important factor, especially in the process of selecting the location. The members of the associations have the opportunity to choose whether to attend a certain meeting - in a special case the attractiveness and the prestigious and unique image of the destination become more important (Opperman \& Chon, 1997). It should be borne in mind that a company employee, participating in a corporate meeting, rarely chooses the destination they visits - it is usually determined by the company, along with travel dates and the overall program, and travel costs are also paid by the company (McCartney, 2007). When organizing government meetings 
and events on high levels, the focus of the travel is on the political issues and decisionmaking, at the expense of the social program during the visit. On the other hand, interest in the economic impact of academic conferences has been steadily growing in recent years. Most destinations have the appropriate infrastructure and facilities to host events of this scale and format, and in this regard, the business meeting industry is globally highly competitive.

In their research, Borghans, Romans and Sauermann (2010) argue that the location of a MICE event is the second most important factor that can shape the decision-making process of potential business tourists regarding their participation in the event (eg a conference). A review of the literature reveals a number of criteria regarding the significance and complexity of the location of a business event Borghans, Romans and Sauermann (2010):

- Destination with infrastructure capable of meeting the needs of both conference organizers (conference and event centers) and the needs of the participants, in terms of accommodation. The infrastructure includes accommodation, meals and entertainment in the destination. In addition we can mention the possibility of the destination to offer cultural attractions and other tourism attractions.

- Destination with historical and cultural heritage, with the possibility to increase the interest of the participants and gradually their number.

- Location with suitable climatic conditions, allowing a pleasant stay in the destination and a smooth conference.

- Destination with the availability of tourist services capable of meeting the needs of visitors in terms of food and entertainment.

- Destination that offers a variety of transportation types for the convenience of tourists. This criterion is associated with easy access to and from the conference venue and is defined as a very important factor for the destination, where the business event takes place.

- Safe destination, with low levels of terrorism, theft and injury. The security assessment criterion is studied by researchers due to the fact that participants prefer to visit a destination they have not visited before.

- Peaceful environment that ensures smooth conferences without conflicts from the local community.

- Destination with reliable health conditions. The possibility of attending business events, which takes place in destinations with a high level of hygiene and cleanliness, without the risk of infectious diseases, is highly valued.

- Destination where the local population uses foreign languages in order to better communicate and provide a high level of service to participants inside and outside the conference room. English is the official language in events characterized by high multiculturalism. Due to their global impact, business events usually attract participants from different countries. It is therefore necessary to adopt a single code of communication between the participants. It 
is an important criterion for assessing the factor "location of the business event", and in this regard for the decision-making process for participation in international events.

The derived criteria in Figure 1. Can be defined as main variables for location evaluation, as well as for organizing and managing business events in it.

Figure 1: Criteria for assessing the attractiveness of the destination. Author's systematization, adapted from Borghans, L., Romans, M., Sauermann (2010)

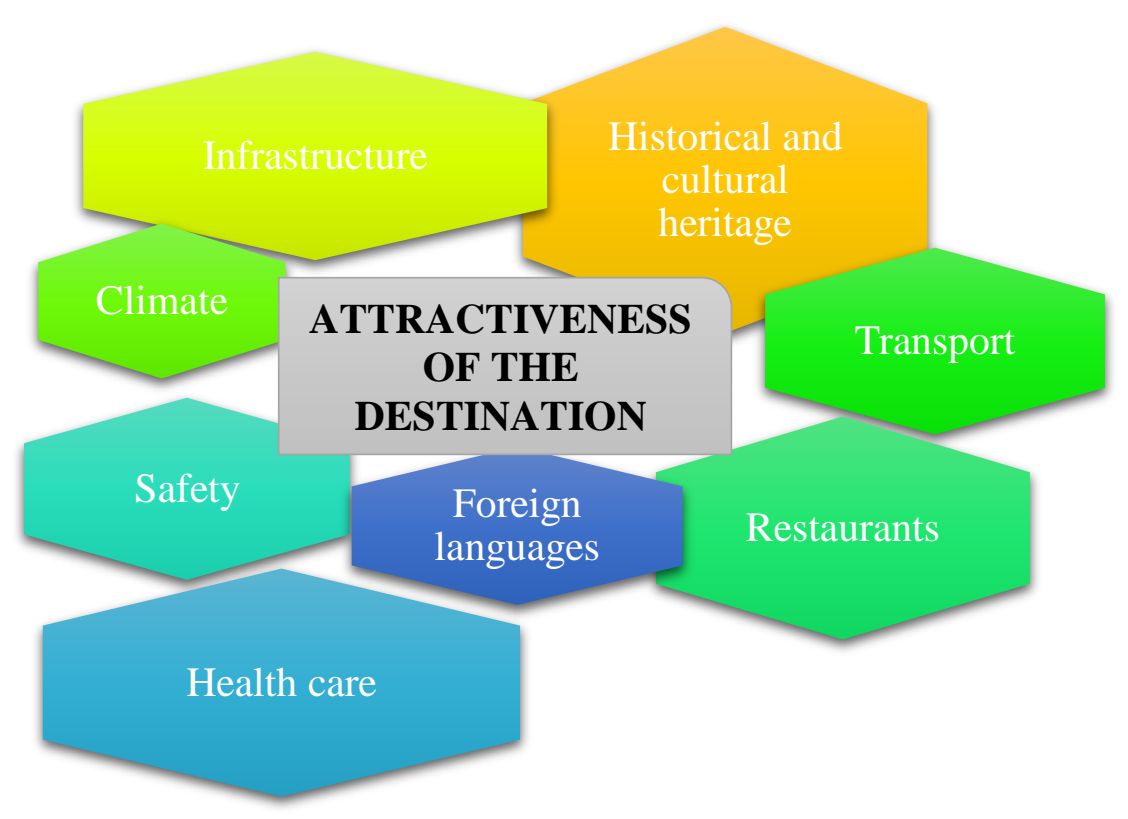

The attractiveness of tourism destinations, as suitable for organizing a MICE event, can be assessed in regards to its cultural and historical heritage, climatic conditions, safety, restaurants, opportunities for entertainment and additional activities, the transportation network, location and other characteristics.

The question of choosing a destination is related to the motives for participation in the business event, and the attractive destination stimulates a larger number of participants. Apart from the location factor, in order to create an image as an attractive destination, important are the opportunities for experiences, which will motivate the potential participants to travel, the provided material and technical base, the cultural heritage and other factors that stand out in the good practices and leading business tourism destinations, discussed in the following exposition.

\section{Good practices in building the image of the destination}

Business meetings can be flexible in terms of destination selection, given the number of large cities and financial capitals suitable and established for hosting MICE 

as a leader in conducting business events can be found in some of the following examples.

France and Spain are among the first leading countries in the number of organized business meetings in recent years. Good transport links and investment in infrastructure, as a result of the opening of a number of new hotels and restaurants, are key factors responsible for the fact that Madrid, Barcelona and Paris are voted as the most popular European cities for hosting business events.

One of the leading user rankings, conducted by the World Travel Awards, sets Madrid, Spain as the most popular destination for meetings and conferences for 2019. According to the same organization, the United Arab Emirates is recognized as the most popular destination for MICE events in the Middle East, along with the UK, Saudi Arabia and India worldwide, identified as key markets. Accessible routes, new hotels and investments in the latest technologies and mechanisms to facilitate the organization of large-scale events put the UAE at the forefront of the rankings. As a leading city in terms of economic indicators in the UAE, in recent years Dubai is positioned as a cosmopolitan destination for business tourism. According to the ranking of the "World Travel Awards", Dubai is a leading destination for MICE tourism for 2019. It might be analysed that this advantage is due to the location of the city - it is strategically located between Europe and Asia and offers the best infrastructure for organizing large events. With the presence of hotels and resorts of the highest level of service, Dubai provides endless opportunities for meetings - on private yachts, outdoor terraces, gardens, private beaches, large ballrooms, exhibition centres and much more. The leading hotel for business events in the world is the Madinat Jumeirah Resort Hotel in Dubai.

Other annual ranking for 2019 - of the International Congress and Convention Association shows that the United States is one of the top MICE destinations - it hosts nearly 900 large-scale business events a year. Following destinations by number of events in 2019 are Germany, France, Spain, Great Britain, Italy, China, Japan and others. There is a tendency for China to give way to the leadership in business events to Japan, which ranks among the 10 most visited in 2019.

The largest number of business events by city in 2019 was in Paris - 237. In second place is Lisbon with 190, followed by Berlin with 176, Barcelona, Madrid, Vienna, Singapore, London and others.

One of the leading European destinations in recent years is Berlin. The German capital is one of the most attractive destinations for business tourism, located in the heart of Europe, by making a connection between the East and West. In this destination tourists can find a rich palette of opportunities for cultural and historical experiences, as well as innovations - on one hand the city houses over 175 museums, part of the world cultural heritage, and on the other hand, when walking around the city you can visit over ten different neighbourhoods with a unique, authentic atmosphere.

London is ranked as a preferred European destination for MICE, due to the 
cultural heritage of the destination, political stability and its convenient location, as the most connecting city in the world with 396 flights to international destinations. A well-known technology hub, UK offers corporate events in more than 1,000 conference rooms and over 140,000 hotel rooms. In addition to the tourist tour, there are 66 Michelin-starred restaurants in the capital.

Uncertainty in the global economy is one of the side factors affecting the MICE industry in the period 2014-2022. Other factors include improving the technological conditions and reducing the cost of organizing virtual conferences, faster and shorter business cycles, and the economic and political impact of Asia's growing economy.

According to experts from the American Express Meetings and Events, the revenues generated from business events in 2018 will be retained and will be key for companies in order to determine strategic business sites. A survey conducted in 2019 with meeting organizers identifies the following trends in the choice of destinations for business events:

- $\quad$ The meetings proposal will be considered in more details by the management of the company;

- It is sought optimization of the costs for the business traveling;

- The non-traditional locations are more attractive - professionals in the field say that they are starting to seek for non-traditional locations for organizing meetings and conferences, such as universities, outdoor places - in nature and unique places for advertising events;

- $\quad$ Respondents fear that a strict policy on adjusting companies' costs will reduce the use of business class air travel and overnight stays in five-star hotels.

The Accor Hotel Group, which owns more than 2,000 hotels specialized in the MICE industry, has noticed major business changes in most of its event-related hotels. Pharmaceutical companies, for example, among the largest consumers of this type of service, are pressuring hotel managers to choose lower-class hotels, leading to an increase in demand for hotels from a rival group, such as Novotel.

According to the study by American Express Meetings and Events, meeting organizers in Europe continue to prefer large cities as destinations - nearly 78\% prioritize this type of destination for business events. Experts in the international MICE industry examine the smaller cities as probably more popular among organizers working on smaller meetings.

A MICE professional in Germany notes: "We are witnessing a growing interest in Eastern Europe - Hungary, Poland and some of the Baltic countries. The organizers make the time spent on a business trip a priority when choosing a location and these destinations are easy to be reached from some parts of Europe and offer high quality services and products and a great price."

Compared to the examined leading destinations for business tourism, important elements can be deduced for forming the image of the destination as attractive for 
business events, namely - high category accommodation, variety of meeting places, opportunities for cultural and historical experiences, entertainment and additional activities, high-tech facilities, as well as innovations in the destination.

\section{Conclusion}

To stimulate the development of the local economy, by organizing large business events, it is necessary to undertake strategic policies for the development of the destination - to invest in innovations, technologies, infrastructure, staff training, marketing policy for destination management and others.

Among the distinctive features of the leading MICE destinations are modernized infrastructure, technological innovations, high quality services, investments in new, modern hotels and high-end dining places, as well as the availability of an effective marketing strategy for destination management. The reviewed examples of good practices in the MICE industry allow us to conclude that the locations placed on the first spots in the world rankings for MICE destinations have similar characteristics - they are established tourism destinations with prerequisites for cultural, historical and other types of tourism; offer a network of large congress and exhibition centres; have a tradition in organizing business events through the use of professional organizers, offices and others.

\section{References}

Borghans, L., Romans, M., Sauermann, J. (2010). What makes a good conference? Analysing the preferences of labour economists, Labour Economics, vol. 17, Issue 5, 868-874.

Ianeva, M. (2020). Developing a methodology for tourism region management (The case of Sofia), Economic studies (6), 2020 Available at: https://www.scopus.com/sourceid/13500154704?origin=recordpage\&fbclid=IwAR1v fZjGQD0KB-eBpGUuy5Uif6KHgGabLF4blSfhfXS7vefOIcmWoplm5RU.

Ladkin, A., Weber, K. (2003). The Convention Industry in Australia and the United Kingdom: Key Issues and Competitive Forces, Journal of Travel Research, Volume: 42, Issue 2.

Kaleychev, S. (2013). Tourist Innovation as the Key to Modernization of Society, Active Citizenship by Knowledge Management \& Innovation: Proceedings of the Management, Knowledge and Learning International Conference, ToKnowPress

Mccartney, G. (2008). A Strategic Use of the Communication Mix in the Destination Image-Formation Process, Journal of Travel Research 47(2):183-196

Oppermann, M. (1996). Convention destination images: analysis of association meeting planners' perceptions, Tourism Management, Volume 17, Issue 3. 
Oppermann, M., Chon, K. (1997). Tourism in Developing Countries, International Thomson Business Press, Berkshire House, London.

Priporas, C. (2005). Is It Difficult to Market a City as a Convention Destination?, Journal of Convention Centers and Event Tourism 7(2).

Tsonev, N. and Kaleychev, S. (2018). Innovative practices as a key for a better management in tourism industry, European Journal of Economics and Business Studies $10(1), 8-16$

\section{Online Sources}

AMEX Meetings and Events, 2019 Global Meetings and Events Forecast. Available at: https://www.amexglobalbusinesstravel.com/content/uploads/2018/10/2019-GlobalMeetings-Events-Forecast_101718-1.pdf

ICCA, Statistics Report. Available at: http://webcache.googleusercontent.com/search?q=cache:_aaQt1kJML4J:www.iccawo rld.org/dcps/doc.cfm\%3Fdocid\%3D2396+\&cd=3\&hl=en\&ct=clnk\&gl=bg

World Travel Awards. World's Leading Meetings \& Conference Destination 2019. Available at:

https://www.worldtravelawards.com/award-worlds-leading-meetings-andconference-destination-2019

World Travel Awards. World's Leading Meetings \& Conference Destination 2019. Available at:

https://www.worldtravelawards.com/award-worlds-leading-meetings-andconference-destination-2019

World Travel Awards. World's Leading Meetings \& Conference Destination 2019. Available at:

https://www.worldtravelawards.com/award-worlds-leading-meetings-andconference-destination-2019 